\title{
SOCIOECONOMIC AND HEALTH CONDITIONS ASSOCIATED WITH QUALITY OF LIFE OF ELDERLY QUILOMBOLAS ${ }^{1}$
}

\author{
Vanessa Cruz Santos², Eduardo Nagib Boery33, Rafael Pereira ${ }^{4}$ Darci de Oliveira Santa Rosa ${ }^{5}$, Alba Benemérita \\ Alves Vilela ${ }^{6}$, Karla Ferraz dos Anjos ${ }^{7}$, Rita Narriman Silva de Oliveira Boery ${ }^{8}$
}

\footnotetext{
${ }^{1}$ Paper taken from the thesis - Quality of life and associated factors among elderly quilombolas, presented to the Programa de PósGraduação em Enfermagem e Saúde (PPGES), Universidade Estadual do Sudoeste da Bahia (UESB), in 2014.

${ }^{2}$ Doctoral student in Public Health, Instituto de Saúde Coletiva (ISC), Universidade Federal da Bahia (UFBA). Salvador, Bahia, Brazil. E-mail: vanessacrus@hotmail.com

${ }^{3}$ Ph.D. in Nursing. Professor, Health Department and PPGES/UESB. Jequié, Bahia, Brazil. E-mail: eboery@gmail.com

${ }^{4}$ Ph.D. in Biomedical Engineering. Professor, Health Department, PPGES/UESB. Jequié, Bahia, Brazil. E-mail: rafaelppaula@ gmail.com

${ }^{5}$ Ph.D. in Nursing. Professor, Undergraduate Program and Programa de Pós-Graduação em Enfermagem (PPGENF), UFBA. Salvador, Bahia, Brazil. E-mail: darcisantarosa@gmail.com

${ }^{6}$ Ph.D. in Nursing. Professor, Departamento de Saúde and PPGES/UESB. Jequié, Bahia, Brazil. E-mail: albavilela@gmail.com

${ }^{7}$ Doctoral student, PPGENF/UFBA. Salvador, Bahia, Brazil. E-mail: karla.ferraz@hotmail.com

${ }^{8}$ Ph.D. in Nursing. Professor, Health Department and PPGES/UESB. Jequié, Bahia, Brazil. E-mail: rboery@gmail.com
}

\begin{abstract}
This study aimed to identify the socioeconomic and health conditions associated with quality of life of elderly quilombolas. Cross-sectional, epidemiological and census study, conducted with 427 elderly individuals of a quilombola population enrolled in Family Health Strategies of 17 quilombas communities in Vitória da Conquista, Bahia, four districts of the region. Data collection was performed using tools and analyzed based on descriptive statistics and Spearman correlation $\left(\mathrm{r}_{\mathrm{sp}}\right)$. The factors associated with some areas of Quality of Life and the General Quality of Life Index included the per capita income, the self-assessment of health status and the classification of depression cases, which most strongly affected the quality of life of the elderly quilombolas investigated. The expanded access to health services and the integrality of health care for this group are essential, particularly involving Family Health Teams.
\end{abstract}

DESCRIPTORS: Quality of life. Health conditions. Mental health. Access to health services. Elderly. Vulnerable communities.

\section{CONDIÇÕES SOCIOECONÔMICAS E DE SAÚDE ASSOCIADAS À QUALIDADE DE VIDA DE IDOSOS QUILOMBOLAS}

RESUMO: Este estudo objetivou identificar as condições socioeconômicas e de saúde associadas à qualidade de vida de idosos quilombolas. Estudo epidemiológico, censitário e transversal, realizado com 427 idosos quilombolas, cadastrados na Estratégia Saúde da Família de 17 comunidades quilombolas de Vitória da Conquista - Bahia, em quatro distritos da região. A coleta de dados foi realizada com os dois instrumentos, analisados a partir da estatística descritiva e de correlação de Spearman $\left(\mathrm{r}_{\mathrm{sp}}\right)$. Entre os fatores associados com alguns domínios da Qualidade de Vida e com o Índice Geral de Qualidade de Vida, estiveram a renda per capita, a autoavaliação do estado de saúde e a classificação dos casos de depressão, que mais impactou na qualidade de vida dos idosos quilombolas pesquisados. É essencial a ampliação do acesso aos serviços de saúde e integralidade da assistência oferecida a esse grupo, em especial pelas Equipes de Saúde da Família.

DESCRITORES: Qualidade de vida. Condições de saúde. Saúde mental. Acesso aos serviços de saúde. Idoso. Comunidades vulneráveis.

\section{CONDICIONES SOCIOECONÓMICAS Y DE SALUD ASOCIADAS CON LA CALIDAD DE VIDA DE ANCIANOS QUILOMBOLAS}

RESUMEN: Este estudio tuvo como objetivo identificar las condiciones socioeconómicas y de salud relacionadas con la calidad de vida de ancianos quilombolas. Estudio epidemiológico, con censo, y transversal, efectuado con 427 ancianos quilombolas, registrados en Estrategias Salud de la Familia de 17 comunidades quilombolas de Vitória da Conquista, Bahía, cuatro distritos de la región. La recogida de datos se realizó con los instrumentos, analizados por estadística descriptiva y correlación de Spearman $\left(\mathrm{r}_{\mathrm{sp}}\right)$. Entre los factores asociados con algunas áreas de la Calidad de Vida y con el Índice General de la Calidad de Vida, se encontraron renta per capita, autoevaluación del estado de salud y clasificación de los casos de depresión, que más afectó a la calidad de vida de los ancianos quilombolas investigados, por lo que se hace imprescindible ampliar el acceso a servicios de salud y haber integralidad en la asistencia ofrecida a este grupo, especialmente por los Equipos de Salud de la Familia.

DESCRIPTORES: Calidad de vida. Condiciones de salud. Salud mental. Acceso a los servicios de salud. Anciano. Comunidades vulnerables. 


\section{INTRODUCTION}

According to law 12.288, about the Statute of Racial Equality, the black population comprises the set of people who, concerning the aspect of color or race, self-declare to be black and/or brown, in accordance with the Brazilian Institute of Geography and Statistics (IBGE), or who adopt an analogue self-definition. ${ }^{1}$

The historical trajectory of the black population in Brazil shows that these individuals have been fighting for better health and quality of life (QoL) conditions. Several rights have been achieved in favor of these improvements, including the universal right to health and social participation. Nevertheless, to reduce the health inequalities black people experience in the country, the social inequalities and poverty level need to be at least minimized and greater equity needs to be possible in the distribution of goods and health services offered to this population.

Between the 1930's and 1980's, different social movements emerged around the world that manifested the black people's dissatisfaction with their QoL to the heads of States. In view of the different manifestations and racial inequalities in Brazil, the National Policy for Integral Health of the Black Population (PNSIPN) was created. Its objectives include the expanded access of the black population, particularly the quilombas communities, to health actions and services. ${ }^{2}$

The quilombas communities consist of black people, descendants of former slaves who got organized in quilombos, settlements that allow them to express their values and traditional practices, based on their slave and African ancestry. These communities are one of the expressions of resistance to the history of social exclusion the black people were victims of in Brazil. ${ }^{3}$

The economic dissatisfaction, as well as the health condition and QoL of a quilombola elderly were verified in an earlier recent study. The difficult access to the health services the Family Health Strategy (FHS) located in the community offers was one of the main complaints, mainly due to the repressed demand and delay to schedule appointments and exams. ${ }^{4}$ This study, involving a person from such a specific population (i.e. a quilombola elderly) also appoints a concerning reality and reveals the need for further and larger studies to better understand the needs of that population. ${ }^{4}$

In Brazil, in accordance with the Health Care Program for Elderly People and Aging, any person aged 60 years or older is called elderly. ${ }^{5}$ Each year, about 650 thousand new elderly are incorporated in the population in the country, most of whom present one or more non-transmissible chronic illnesses (NTCI), besides functional limitations, which can interfere in the QoL. Hence, the evolution of these limitations needs to be postponed to guarantee an autonomous and independent long life with a better QoL. ${ }^{6}$

In view of the above, studies are justified to identify the QoL and associated factors among quilombola elderly, individuals who are part of vulnerable communities, which can support managers and health professionals in their need to create actions that can favor the promotion of these elderly people's health and QoL.

In that perspective, the objective in this study is to identify the socioeconomic and health conditions associated with the quality of life of quilombas elderly.

\section{METHOD}

Epidemiological census study with a crosssectional design, undertaken in the city of Vitória da Conquista-BA and in four rural districts in that region, involving 427 quilombas elderly from 17 communities, remainders of quilombos, located in rural areas covered by the FHS: Boqueirão (José Gonçalves), Quatís dos Fernandes and Furadinho (Iguá), Corta Lote, Cachoeira do Rio Pardo (Inhobim), Baixa Seca, Lagoa de Melquíades, Velame (Veredinha) and Lagoa de Maria Clemência (Pradoso), located in the headquarters. This territory is divided among the communities Oiteiro, Riacho de Téofilo, Baixão, Tábua, Manoel Antonio, Poço de Aninha, Muritiba and Caldeirão.

The city Vitória da Conquista is located in the Southwest of Bahia - Brazil, with a territory of $3,405.580 \mathrm{~km}^{2}$ and a population of 306,866 inhabitants. In the urban area, there are 274,739 inhabitants, 27,098 of whom are elderly. In the rural people, there are 32,127 inhabitants, with 3,651 elderly. Since 1840, the colonizers and the black slaves have participated in the city, contributing and being responsible for the main workforce on the fields. The heritage of the black people is present in different aspects of the city's culture and in the quilombas communities. ${ }^{7}$

The data were collected between January and April 2014, after applying the research tools through a pretest (pilot), applied in a quilombola community that had applied for certification from the Fundação Cultural Palmares (FCP $)^{8}$ and which presented characteristics similar to the communities included in 
this study. The pilot was also used to train the team of interviewers and to check the applicability of the research tools. As a result, the need was identified to exclude the World Health Organization Quality of Life instrument for older adults (WHOQOL-old), due to the predominance of elderly people who felt uncomfortable about answering questions on the facet Death and Dying of that tool.

The inclusion criteria adopted in this study were: age 60 years or older, self-declare to live in quilombos, brown or black, living in communities remainders of acknowled ged quilombos certified by FCP, having a FHS within the territory and being enrolled at one of the services; having preserved cognitive functions, according to the Mini-Mental State Examination (MMSE). The exclusion criterion was: elderly people who were not found for the interview, after three visits on distinct days and times.

To survey the elderly registered in the FHS of the quilombas communities, a search was undertaken in Forms A of each strategy, revealed 449 registered elderly. Next, through home visits, they were selected at home.

The interview technique was chosen to apply the tools, starting with the MMSE, elaborated for cognitive functional assessment, ${ }^{9}$ validated in Brazil, ${ }^{10}$ and divided in several domains, including orientation to time and place, immediate and recall memory, calculation, language-naming, repetition, understanding, writing and copying of a drawing. ${ }^{9-10}$ This tool was assessed by means of the suggested cut-off points, according to the person's education level: illiterate - 20 points; between one and four years - 25; between five and eight years - 26.5; between nine and 11 years - 28; for individuals with $>11$ years of education $-29 .{ }^{11}$

Based on the assessment of the MMSE, 22 elderly were excluded due to non intact cognitive functioning, as indicated by the minimum MMSE score, one of the inclusion criteria established in this study. Thus, in total, 427 quilombola elderly were investigated.

Next, to assess the independent study variables, the questionnaire Brazil Old Age Schedule (BOAS) was applied, which assessed the socioeconomic and health characteristics of the elderly. This tool was elaborated in England in 1986 and translated in Brazil by Veras and Dutra in 2008. The tool is considered functional, multidimensional and appropriate for community-based studies in the elderly population. It contains 81 questions, 75 focused on the study participants and six on the interviewer, distributed in IX sections: I - general information,
II - physical health, III - use of medical and dental services, IV - Activities of daily living (ADLs), V - social resources, VI - economic resources, VII mental health, VIII - needs and problems affecting the interviewee, IX- interviewer's assessment. ${ }^{12}$

The section on the ADLs is divided in two blocs, the first of which refers to the activities the elderly person is able to accomplish alone, while the second relates to the leisure activities that person participates in. Each activity accomplished corresponds to one point. In the first bloc, the score varies between 0 and 15 , and the second between 0 and 17 , without any cut-off point. ${ }^{12}$

The following ADLs which the elderly are able to perform alone were assessed: going out using transportation; going out driving one's own car; going out for short distances; preparing one's meal; eating one's meal; arranging the house, one's bed; taking one's medicines; dressing; combing one's hair; walking on a level surface; climbing up/down the stairs; getting in/out of bed; showering; cutting one's toenails; getting to the bathroom in time. The ADLs the elderly participate in during their free time were: listening to the radio; watching television; reading the newspaper; reading magazines and books; getting visitors; going to the movies, theater etc.; walking around one's neighborhood; going to church; attending sports games; practicing sports; buying groceries; going out to visit friends; going out to visit relatives; going out on excursions; going out for social or community meetings; sowing, embroidering, knitting; doing anything for distraction. ${ }^{12}$

To assess the mental health section of the BOAS, specifically the classification of depression cases, the Short-Care scale was applied, using the scoring system validated in Brazil. Elderly scoring between eight and 12 were classified as cases of minor depression, while scores between 13 and 28 , which is the maximum score, were classified as major depression. ${ }^{13}$

Finally, to assess the elderly's QoL, the dependent variable in this study, the elderly answered the World Health Organization Quality of Life (WHOQOL-bref) questionnaire, validated in Brazil. This tool contains 26 questions, two of which are general questions that assess the general quality of life and satisfaction with health, while 24 cover the physical, psychological, social relationships and environmental domains. The two general questions are calculated in combination, resulting in a single score called the General Quality of Life (GQoL) index, independently of the other domain scores. 
The higher the score on this questionnaire, ranging from zero to 100, the better the QoL. Nevertheless, there are no established cut-off points. ${ }^{14}$

The collected data were processed in the Statistical Package for the Social Sciences (SPSS) software, version 21.0. The analysis was based on descriptive statistics, using the mean, median, range and standard deviation $( \pm)$. In addition, Spearman's correlation between the dependent variables was used, which were the domains of the WHOQOLbref (Physical, Psychological, Environmental and Social Relationships) and the GQoL, and the independent variables, which were the variables related to the socioeconomic (education, monthly individual income, monthly family income and per capita income) and health conditions (self-assessed health status, number of health problems, self-assessment of dental conditions, number of medicines taken, satisfaction with health service, number of activities accomplished alone, number of leisure activities and classification of depression cases). Significance was set at five percent in this study.

This research complies the Resolution 466/2012 of Conselho Nacional de Saúde. Approval was obtained from the Research Ethics Committee of Universidade Estadual do Sudoeste da Bahia, Jequié campus, under protocol 509.987 and CAAE 24568313.4.0000.0055.

\section{RESULTS}

Among the 427 quilombola elderly, 53.6\% were female, $82.2 \%$ illiterate, $53.2 \%$ brown (Table 1 ).

Table 1 - Socioeconomic characteristics of quilombola elderly. Vitória da Conquista-BA, Brazil, 2014. $(\mathrm{n}=427)$

\begin{tabular}{lrr}
\hline Categorical variables & $\mathbf{n}$ & $\mathbf{0}$ \\
\hline Sex & & \\
$\quad$ Male & 198 & 46.4 \\
$\quad$ Female & 229 & 53.6 \\
Education & & \\
$\quad$ None/Illiterate & 351 & 82.2 \\
Primary & 68 & 15.9 \\
$\quad$ Secondary & 8 & 1.9 \\
Race/color & & \\
$\quad$ Black & 200 & 46.8 \\
$\quad$ Brown & 227 & 53.2 \\
\hline
\end{tabular}

The mean age was 71 years $( \pm 8.09)$, the mean monthly individual income $\mathrm{R} \$ 806.46( \pm 304.81)$, the mean monthly family income $\mathrm{R} \$ 1,166.05( \pm 397.27)$, and the mean per capita income $\mathrm{R} \$ 417.32( \pm 231.81)$. The minimum wage valid at the time of the study was $\mathrm{R} \$ 724.00$ (Table 2).

Table 2 - Socioeconomic characteristics of quilombola elderly. Vitória da Conquista-BA, Brazil, 2014. $(n=427)$

\begin{tabular}{lcccc}
\hline Continuous variables & Mean & Standard deviation & Minimum & Maximum \\
\hline Age (in years) & 71 & 8.09 & 60 & 102 \\
Monthly individual income $(\mathrm{R} \$)^{*}$ & 806.46 & 304.81 & 0.00 & $1,448.00$ \\
Family income $(\mathrm{R} \$)^{*}$ & $1,166.05$ & 397.27 & 0.00 & 2,172 \\
Per capita income $(\mathrm{R} \$)^{*}$ & 417.32 & 231.81 & 0.00 & $1,448.00$ \\
\hline
\end{tabular}

${ }^{*}(\mathrm{R} \$)=$ Reais

Concerning the self-assessed health status, the most prevalent answer was bad $(48.9 \%)$. Among the elderly who indicated health problems, $82.6 \%$ had between one and five problems, the most frequent of which were: systemic arterial hypertension $(73.86 \%)$, back problems $(17.86 \%)$, diabetes mellitus (15.46\%) and hypercholesterolemia $(13.06 \%)$. In the assessment of the dental conditions, the most prevalent assessment (39.1\%) was bad, keeping in mind that the edentulous elderly referred to the conditions of their prosthesis (Table 3).

Regarding the use of medicines, $76.3 \%$ of the elderly mentioned taking $2.63( \pm 1.62)$ medicines on average, ranging between one and 13 types per day. As regards the satisfaction with the health service, dissatisfied individuals prevailed (57.8\%), followed by individuals who do not take or do not need medicines (25.1\%) (Table 3).

Among the 15 activities assessed which the elderly was able to accomplish alone, $93.4 \%$ performed between eight and 15, the most frequent of which were: getting in/out of bed (98.1\%); combing one's hair (97.0\%); dressing and walking on a level surface $(96.5 \%)$. Among the 17 activities the elderly participated in during their free time, $82.0 \%$ participated in one to eight activities, the most frequent of which were: watching television (91.1\%), listening 
to the radio $(83.6 \%)$ and going out to visit friends (80.1\%) (Table 3).

In the assessment of the elderly's mental health using the Short-Care scale, the prevalence rate of depression among the elderly corresponded to $29.5 \%$, $26.2 \%$ presenting minor depression or depression and $3.3 \%$ major depression (Table 3 ).

Table 3 - Health characteristics of quilombola elderly. Vitória da Conquista-BA, Brazil, 2014. $(n=427)$

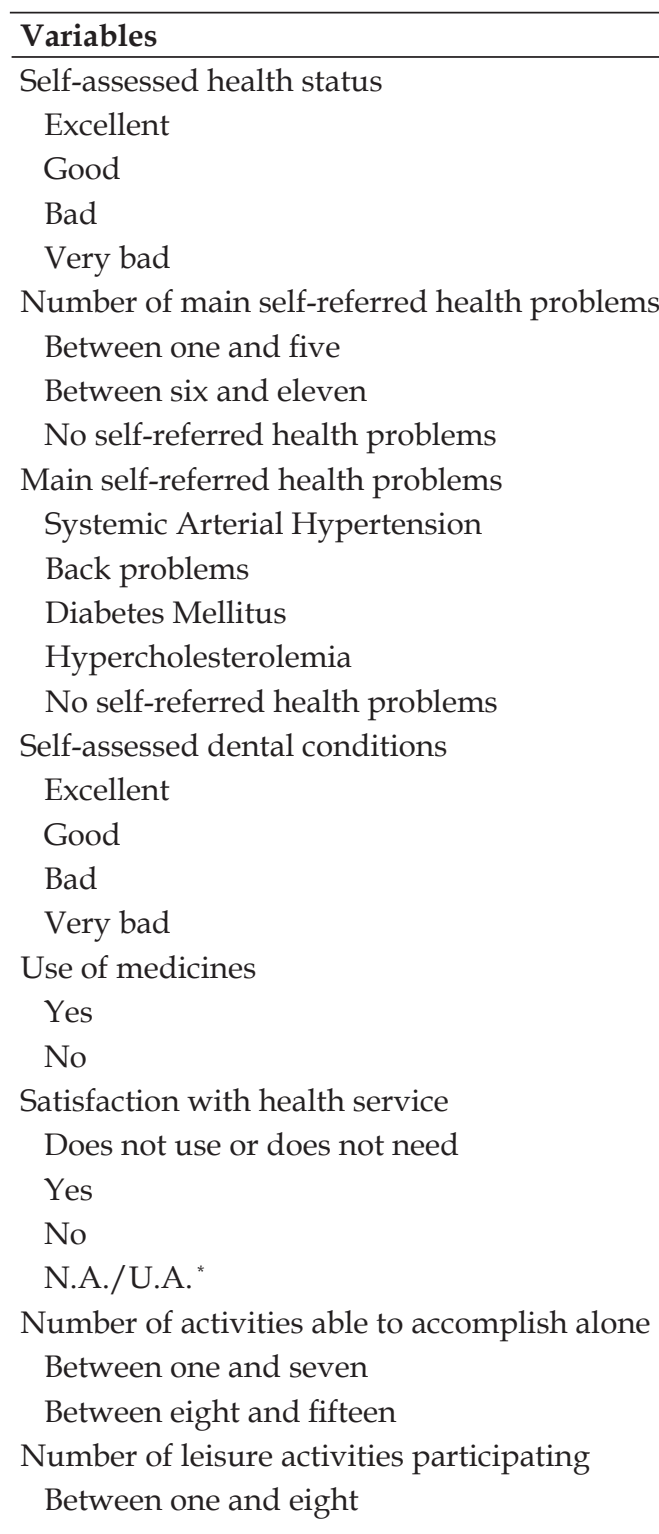
$173 \quad 40.5$ 20948.9

$31 \quad 7.3$

$353 \quad 82.7$

$\begin{array}{ll}22 & 5.1\end{array}$

$52 \quad 12.2$

$277 \quad 73.8$

$\begin{array}{lll}67 & 17.8\end{array}$

$58 \quad 15.4$

$49 \quad 13.0$

$52 \quad 12.2$

20.5

11126.0

$167 \quad 39.1$

$147 \quad 34.4$

32676.3

$101 \quad 23.7$

$107 \quad 25.1$

$71 \quad 16.6$

$247 \quad 57.8$

$2 \quad 0.5$

$28 \quad 6.6$

39993.4

$350 \quad 82.0$

\begin{tabular}{lrr}
\hline Variables & n & \% \\
\hline Between nine and 17 & 77 & 18.0 \\
Classification of depression cases & & \\
No case of depression & 301 & 70.5 \\
Minor depression/depressed & 112 & 26.2 \\
Major depression & 14 & 3.3 \\
\hline
\end{tabular}

"N.A./U.A. =Did not answer or was unable to answer.

In the WHOQOL-bref, the mean GQoL was 48.00 ( \pm 19.93$)$. The domains with the highest scores were Social (mean 71.09; median $75.00 ; \pm 8.97$ ) and Psychological (mean 56.06; median 54.16; \pm 11.71 ). The Physical (mean 50.83; median 53.57; \pm 11.75 ) and Environmental domains (mean 44.63; median 43.75; \pm 8.94 ) presented the lowest scores.

Tables 4 and 5 present the correlations between the BOAS sections, related to: social and economic resources; health conditions; use of medical and dental services; ADLs. Among the findings, the variable per capita income showed a strong and significant negative correlation with all domains and the GQoL, also found in the mental health section, specifically concerning the variable depression.

Table 4 - Socioeconomic factors associated with the quality of life of elderly quilombolas based on Spearman's correlation coefficients $\left(r_{\text {sp }}\right)$ between the domains and the GQoL of the WHOQOL-bref and BOAS variables, Vitória da Conquista-BA, Brazil, 2014. $(n=427)$

\begin{tabular}{lcccc}
\hline $\begin{array}{c}\text { WHOQOL- } \\
\text { bref do- } \\
\text { mains }\end{array}$ & $\begin{array}{c}\text { Educa- } \\
\text { tion }\end{array}$ & $\begin{array}{c}\text { Monthly } \\
\text { individu- } \\
\text { al income }\end{array}$ & $\begin{array}{c}\text { Family } \\
\text { income }\end{array}$ & $\begin{array}{c}\text { Per } \\
\text { capita } \\
\text { income }\end{array}$ \\
\hline Environ- & -0.066 & $0.132^{\dagger}$ & $0.112^{*}$ & $0.146^{\dagger}$ \\
mental & $(0.174)$ & $(0.006)$ & $(0.021)$ & $(0.003)$ \\
Physical & -0.039 & -0.010 & 0.051 & $0.131^{\dagger}$ \\
Psychologi- & $(0.425)$ & $(0.840)$ & $(0.292)$ & $(0.007)$ \\
cal & $-0.157^{\dagger}$ & -0.043 & 0.043 & $0.156^{\dagger}$ \\
Social Rela- & $(0.001)$ & $(0.374)$ & $(0.374)$ & $(0.001)$ \\
tionships & 0.045 & $0.104^{*}$ & $0.128^{\dagger}$ & $0.158^{\dagger}$ \\
GQoL & $-0.355)$ & $(0.032)$ & $(0.008)$ & $(0.001)$ \\
\hline
\end{tabular}

${ }^{*}$ Statistically significant correlation $(\mathrm{p}<0.05) ;{ }^{\dagger}$ Statistically significant correlation $(\mathrm{p}<0.01)$. 
Table 5 - Health factors associated with quality of life of elderly quilombolas based on Spearman's correlation coefficients $\left(\mathrm{r}_{\mathrm{sp}}\right)$ between the domains and the GQoL of the WHOQOL-bref and BOAS variables, Vitória da Conquista-BA, Brazil, 2014. ( $\mathrm{N}=427)$

\begin{tabular}{|c|c|c|c|c|c|c|c|c|}
\hline 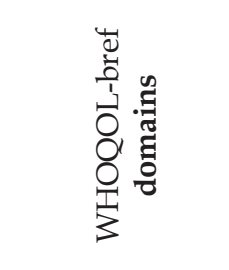 & 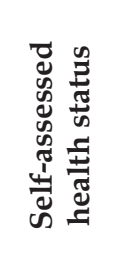 & 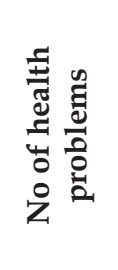 & 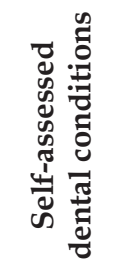 & 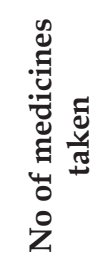 & 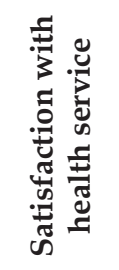 & 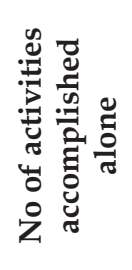 & 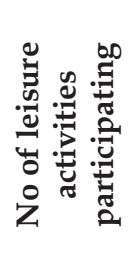 & 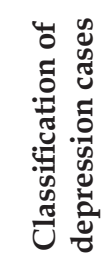 \\
\hline Environmental & $\begin{array}{l}-0.394^{\dagger} \\
(0.000)\end{array}$ & $\begin{array}{l}-0.327^{\dagger} \\
(0.000)\end{array}$ & $\begin{array}{l}-0.216^{\dagger} \\
(0.000)\end{array}$ & $\begin{array}{c}0.144^{\dagger} \\
(0.009)\end{array}$ & $\begin{array}{c}-0.289^{\dagger} \\
(0.000)\end{array}$ & $\begin{array}{c}0.199^{\dagger} \\
(0.000)\end{array}$ & $\begin{array}{c}0.216^{\dagger} \\
(0.000)\end{array}$ & $\begin{array}{l}-0.346^{\dagger} \\
(0.000)\end{array}$ \\
\hline Physical & $\begin{array}{l}-0.441^{\dagger} \\
(0.000)\end{array}$ & $\begin{array}{l}-0.437^{\dagger} \\
(0.000)\end{array}$ & $\begin{array}{l}-0.223^{\dagger} \\
(0.000)\end{array}$ & $\begin{array}{c}0.255^{\dagger} \\
(0.000)\end{array}$ & $\begin{array}{l}-0.211^{+} \\
(0.000)\end{array}$ & $\begin{array}{c}0.260^{\dagger} \\
(0.000)\end{array}$ & $\begin{array}{c}0.265^{\dagger} \\
(0.000)\end{array}$ & $\begin{array}{c}-0.280^{\dagger} \\
(0.000)\end{array}$ \\
\hline Psychological & $\begin{array}{l}-0.258^{\dagger} \\
(0.000)\end{array}$ & $\begin{array}{l}-0.201^{*} \\
(0.000)\end{array}$ & $\begin{array}{l}-0.202^{\dagger} \\
(0.000)\end{array}$ & $\begin{array}{c}0.062 \\
(0.260)\end{array}$ & $\begin{array}{c}-0.203^{\dagger} \\
(0.000)\end{array}$ & $\begin{array}{c}0.148^{\dagger} \\
(0.002)\end{array}$ & $\begin{array}{c}0.137^{\dagger} \\
(0.005)\end{array}$ & $\begin{array}{l}-0.340^{\dagger} \\
(0.000)\end{array}$ \\
\hline Social relations & $\begin{array}{l}-0.122^{*} \\
(0.012)\end{array}$ & $\begin{array}{l}-0.182^{\dagger} \\
(0.000)\end{array}$ & $\begin{array}{l}-0.076 \\
(0.118)\end{array}$ & $\begin{array}{l}-0.083 \\
(0.135)\end{array}$ & $\begin{array}{l}-0.164^{\dagger} \\
(0.003)\end{array}$ & $\begin{array}{c}0.001 \\
(0.978)\end{array}$ & $\begin{array}{l}-0.017 \\
(0.722)\end{array}$ & $\begin{array}{l}-0.142^{\dagger} \\
(0.003)\end{array}$ \\
\hline GQoL & $\begin{array}{l}-0.705^{\dagger} \\
(0.000)\end{array}$ & $\begin{array}{l}-0.623^{\dagger} \\
(0.000)\end{array}$ & $\begin{array}{l}-0.378^{\dagger} \\
(0.000)\end{array}$ & $\begin{array}{c}0.272^{\dagger} \\
(0.000)\end{array}$ & $\begin{array}{c}-0.414^{\dagger} \\
(0.000)\end{array}$ & $\begin{array}{c}0.155^{\dagger} \\
(0.001)\end{array}$ & $\begin{array}{c}0.146^{\dagger} \\
(0.002)\end{array}$ & $\begin{array}{l}-0.449^{\dagger} \\
(0.000)\end{array}$ \\
\hline
\end{tabular}

* Statistically significant correlation $(\mathrm{p}<0.05) ;{ }^{\dagger}$ Statistically significant correlation $(\mathrm{p}<0.01)$.

\section{DISCUSSION}

In this study, the factors associated with the QoL of elderly quilombolas were analyzed individually for the four domains of the WHOQOL-bref (Environmental, Physical, Psychological and Social Relations) as well as the GQoL.

The Social Relations domains revealed the highest mean score among the QoL domains assessed in this study, followed by the Psychological domain. Nevertheless, the Environmental domain, followed by the Physical domain, presented the lowest mean scores among the QoL domains. These results diverge from an international study involving rural elderly, ${ }^{15}$ showing higher mean scores for the Environmental domain and worse scores for the Physical domain, similar to a study involving Brazilian urban elderly, ${ }^{16}$ showing higher scores for the Social Relations domain and lower scores for the Physical domain.

Considering that the Environmental domain most strongly influenced the QoL of the elderly quilombolas, differently from other studies cited above, these findings may be related to the environmental aspects of the places where people in quilombola settlements live. That is so because several of these communities are characterized by a lack of basic sanitation, inappropriate hygiene and absence of treated water, besides deficient health care and lack of transportation. ${ }^{17}$

Education was strongly associated with the mean score in the Psychological domain. These results differ from the findings in a study ${ }^{18}$ that identified a positive QoL in elderly people with low education levels, mainly in the Social and Physical domains. In another study ${ }^{19}$, however, it was identified that elderly people with a higher education level perceived a better QoL in the Social Relations domain.

Concerning the economic resources, the participants' monthly individual income showed a negative relation with the Environmental and Social Relations domains and the GQoL. These results differ from a study ${ }^{20}$ in which the elderly's income positively influenced the perceived QoL. What the monthly family income of the elderly quilombolas is concerned, an association was found with the Environmental and Social Relations domains of QoL. These results are partially similar to the findings in a study ${ }^{21}$ that showed associations with the Environmental and Physical domains.

In addition, the analysis of the elderly's per capita income in this study showed a relation with all domains and with the GQoL. These findings may be related with the high rate of low-income elderly people (less than one minimum wage). This hypothesis can be ratified based on the study results ${ }^{20}$, in which people with an individual monthly income of more than five minimum wages performed better on the Environmental domain of QoL.

The economic condition is a relevant intervening factor that directly influences the lives of the 
quilombas families. On several occasions, as they do not gain a sufficiently high family income, the families do not get an appropriate diet, resulting in dietary shortages and low nutritional quality, which can negatively influence their health condition. ${ }^{17}$ Thus, the economic conditions can negatively influence the QoL of quilombas elderly who, besides these factors, experience other conditions that are unfavorable to healthy aging.

The self-assessed health status was strongly associated with the QoL and GQoL, except for the Social Relations domain, which was also associated but less intensely. These results are similar to the associated with the Social Relations domain of elderly people's QoL found in another study.2. In addition, in a study that assessed the QoL of elderly people, it was evidenced that the elderly's background health conditions are one of the factors that most influenced the perceived QoL. ${ }^{19}$

The number of main health problems in the elderly was strongly associated with the QoL and GQoL, except for the Psychological domain that, although less intense, interfered negatively in the QoL. In an international study on QoL and ADLs of elderly people in rural areas, developed in Turkey, based on the WHOQOL-bref, it was verified that the presence of diseases was associated with lower scores in the Physical, Psychological and Social domains. ${ }^{15}$

The self-assessment of the dental conditions showed no significant association, except with the Social Relations domain. As the study involved brown and black elderly, these results may be related with the access difficulties to dental services as, according to a study about race and use of oral health services among elderly people, it was evidenced that the chance of a black elderly person never having been attended by a dentist is more than twice as high as for white elderly. ${ }^{23}$

The number of medicines negatively influences the Environmental and Physical domains of the studied elderly's QoL and GQoL. These findings are similar to the study ${ }^{22}$ in which a negative influence was found in the Physical domain. Nevertheless, a positive relation was found between medication use and the Psychological and Social Relations domains of the elderly quilombolas' QoL, which may be related with the positive response the medicine may have provided to these elderly people's health conditions. Nevertheless, not all medicines and the way they are being used can represent positive effects on these people's QoL.

In a study developed in quilombas communities, it was identified that the number of self-referred mor- bidities, which appointed chronic health problems among the participants, was related to medication use, which elderly people are more prone to. Therefore, elderly people are preferential targets of health promotion strategies that can contribute to rational medication use, ${ }^{24}$ thus minimizing the occurrence of negative impacts in this population group.

The variable satisfaction with health services showed a strong association with all domains of QoL and with the GQoL. These results may be related with the findings of the study developed in a quilombola community in Southwestern Bahia, in which the underuse of health services was identified, thus suggesting greater difficulty and dissatisfaction with the access in the quilombola population. ${ }^{25}$

In the analysis of the ADLs, the smaller the number of activities the elderly was unable to accomplish alone, the lesser the contribution to the QoL, except for the social relations domain. This was hardly similar to a study on the functional ability, morbidities and QoL of elderly people ${ }^{16}$, in which an association was found in the Physical domain only.

Concerning the number of leisure activities the elderly participated in, the lower the number, the worse the contribution to the QoL, except for the social relations domain. Elderly participants in a study ${ }^{26}$ referred to the importance of leisure activities and occupation to maintain their QoL.

Based on the assessment of the classification of depression cases (no case of depression, minor depression/depressed or major depression), a strong association was evidenced with all QoL domains assessed and with the GQoL. These findings are similar to a study developed in rural China, in which mental health was the factor that most compromised the QoL of the elderly studied. ${ }^{27}$

Based on a study about depression in quilombas communities, the authors suggest investments in infrastructure, sanitation, education and access to health services, as well as training health professionals to screen for depression cases in this population, which can contribute to improve the living conditions, as well as the identification and early treatment of several health problems like depression. ${ }^{28}$

In view of the elderly population, the identification of depression cases in this social segment is fundamental in clinical practice, considering that it can contribute to the development of appropriate interventions and the prevention of possible diseaserelated risk factors. ${ }^{29}$ In addition, it can contribute to improve the QoL of elderly suffering from this health problem. 
In view of the results, it is highlighted that this study comes with limitations related to the use of a cross-sectional design to indicate associations between the variables, considering that the possibility of reverse causality is a characteristic of this design. In addition, some elderly found it difficult to understand some questions in the WHOQOL-bref.

\section{CONCLUSION}

As identified, the variables related to the health conditions contributed less to the elderly people's quality of life than the socioeconomic variables, mainly the variable depression case. Therefore, it is suggested that the development of implementation of actions to improve these individuals' health conditions should be prioritized, emphasizing mental health promotion, prevention of resulting implications and specialized treatment.

In addition, the access to health services needs to be expanded and integral health care and care continuity needs to be offered to the elderly, especially by the FHS located in the quilombas communities they live in, besides improvements in the socioeconomic conditions, considering that these can modulate the elderly's health conditions and, consequently, their QoL.

Thus, the researchers hope that the health services and professionals will be able to recognize the most evident problems on the quilombola territory and try to respond to the demands of the investigated elderly, contributing to the concrete transformation of the reality found in this study and thus supporting the legitimation of the right to better health conditions for these elderly people.

\section{REFERENCES}

1. Brasil. Lei $n^{\circ} 12.288$, de 20 julho de 2010. Institui sobre a Igualdade Racial. Presidência da República Casa Civil Subchefia para Assuntos Jurídicos, 20 julho de 2010.

2. Ministério da Saúde (BR). Política Nacional de Saúde Integral da População Negra. Secretaria Especial de Políticas de Promoção da Igualdade Racial - SEPPIR. Brasília (DF): MS; 2007.

3. Bennett M. Os quilombolas e a resistência. Rev Palmares: Cultura Afro-Brasielira [online]. 2010 mar [cited 2015 Out 01]; 6(6):29-36. Available from: http://www.palmares.gov.br/wp-content/ uploads/2011/02/revista06.pdf

4. Santos VC, Boery EN, Boery RNSO, Anjos KF. Conditions of health and quality of life of the quilombola elderly black. J Nurs UFPE on line [online]. 2014 ago [cited 2015 Out 01]; 8(8):321-7.
Available from: file:// C:/Users/Pontocom $\% 20$ Informatica/Downloads/6300-60379-1-PB\%20(3).pdf

5. Ministério da Saúde (BR). Atenção à saúde da pessoa idosa e envelhecimento. Secretaria de Atenção à Saúde, Departamento de Ações Programáticas e Estratégicas. Brasília (DF): MS; 2010.

6. Veras R. Population aging today: demands, challenges and innovations. Rev Saúde Pública [online]. 2009 [cited 2015 Out 01]; 43(3):1-7. Available from: http:/ / www.scielo.br/pdf/rsp/v43n3/en_224.pdf

7. Instituto Brasileiro de Geografia e Estatística. Censo Demográfico 2010 [Internet]. Brasília (DF): IBGE; 2010 [cited 2015 Out 01]. Available from: http://cidades. ibge.gov.br/xtras/perfil.php?codmun=292740

8. Fundação Cultural Palmares [Internet]. Brasília (DF); 2015 [cited 2015 Out 01]. Available from: http://www. palmares.gov.br/

9. Folstein MF, Folstein SE, McHugh PR. Mini-mental state: a practical method for grading the cognitive state of patients for the clinicians. J Psychiatr Res. 1975;12: 189-98

10. Bertolucci PHF, Brucki MDS, Campacci SR, JulianoY. O Mini Exame do Estado Mental em uma população geral: impacto da escolaridade. Arq Neuro-Psiquiatr [online]. 1994 [cited 2015 Out 01]; 52:1-7. Available from: http://www.scielo.br/pdf/anp/v52n1/01.pdf

11. Brucki SMD, Nitrini R, Caramelli P, Bertolucci PHF, Okamoto IH. Sugestões para o uso do Mini-Exame do estado mental no Brasil. Arq Neuro-Psiquiatr [online]. 2003 [cited 2015 Out 01]; 61: 777-81. Available from: http://www.scielo.br/pdf/anp/v61n3B/17294.pdf

12. Veras RP, Dutra S. Perfil do idoso brasileiro: Questionário Boas. Rio de Janeiro (RJ): UERJ, UnATI, 2008.

13. Veras RP. País jovem com cabelos brancos: a saúde do idoso no Brasil. Rio de Janeiro (RJ): Relume Dumará; 1994.

14. Fleck MPA, Louzada S, Xavier M, Chachamovich E, Vieira G, Santos L, et al. Aplicação da versão em português do instrumento abreviado de avaliação da qualidade de vida "WHOQOL-bref". Rev Saúde Pública [online]. 2000 [cited 2015 Out 01]; 34(2):17883. Available from: http://www.scielo.br/pdf/rsp/ v34n2/1954.pdf

15. Arslantas D, Unsal A, Metintas S, Koc F, Arslantas A. Life quality and daily life activities of elderly people in rural areas, Eskisehir (Turkey). Arch Gerontol Geriatr. 2009; 48:127-31

16. Tavares DMS, Dias FA. Functional capactiy, morbidities and quality of life of the elderly. Texto Contexto Enferm [online]. 2012 [cited 2015 Out 01]; 21(1):112-20. Available from: http:/ / www.scielo.br/ pdf/tce/v21n1/en_a13v21n1.pdf

17. Freitas DA, Caballero AD, Marques AS, Hernández CIV, Antunes SLNO. Saúde e comunidades quilombolas: uma revisão da literatura. Rev CEFAC 
[online]. 2011 set-out [cited 2015 Out 01]; 13(5):937-943. Available from: http://www.scielo.br/pdf/rcefac/ v13n5/151-10.pdf

18. Braga MCP, Casella MA, Campos MLN, Paiva SP. Qualidade de vida medida pelo whoqol-bref: estudo com idosos residentes em Juiz de Fora/MG. Rev APS [online]. 2011 [cited 2015 Out 01]; 14(1):93-100. Available from: http://aps.ufjf.emnuvens.com.br/ aps/article/view/965/450

19. Vitorino LM, Paskulin LMG, Vianna LAC. Quality of life of seniors living in the community and in long term care facilities: a comparative study. Rev Latinoam Enfermagem [online]. 2013 [cited 2015 Out 01]; 21(Spec):3-11. Available from: http://www.scielo. $\mathrm{br} / \mathrm{pdf} / \mathrm{rlae} / \mathrm{v} 21 \mathrm{nspe} / 02 . \mathrm{pdf}$

20. Alexandre TS, Cordeiro RC, Ramos LR. Factors associated to quality of life in active elderly. Rev Saúde Pública [online]. 2009 [cited 2015 Out 01]; 43(4):61321. Available from: http://www.scielo.br/pdf/rsp/ v43n4/58.pdf

21. Pereira KCR, Angela MA, Jefferson LT. Contribuição das condições sociodemográficas para a percepção da qualidade de vida em idosos. Rev Bras Geriatr Gerontol [online]. 2011 [cited 2015 Out 01]; 14(1):8595. Available from: http://www.scielo.br/pdf/rbgg/ v14n1/a10v14n1.pdf

22. Nóbrega TCM, Jaluul O, Machado AN, Paschoal SMP, Jacob Filho W. Quality of Life and multimorbidity of elderly outpatients. Clinics. 2009; 64: 45-50

23. Souza EA, Oliveira PAP, Paegle AC, Goes PSA. Raça e o uso dos serviços de saúde bucal por idosos. Ciênc Saúde Coletiva [online]. 2012 [cited 2015 Out 01]; 17(8):2063-70. Available from: http:/ / www.scielosp. org/pdf/csc/v17n8/17.pdf

24. Medeiros DS, Moura CS, Guimarães MDC, Acurcio FA. Medication use by the "quilombola" population: a survey in Southwestern Bahia, Brazil. Rev Saúde Pública [online]. 2013 [cited 2015 Out 01]; 47(5):905-13. Available from: http:/ / www.scielosp.org/pdf/rsp/ v47n5/en_0034-8910-rsp-47-05-0905.pdf

25. Gomes KO, Edna AR, Mark DCG, Mariângela LC. Utilização de serviços de saúde por população quilombola do Sudoeste da Bahia, Brasil. Cad Saúde Pública [online]. 2013 Set [cited 2015 Out 01]; 29(9):1829-42. Available from: http:/ / www.scielosp. org/pdf/csp/v29n9/a22v29n9.pdf

26. Teston EF, Marcon SS. Quality of life and living conditions from the viewpoint of residents in a seniors condominium. Rev Gaúcha Enferm [online]. 2014 Mar [cited 2015 Out 01]; 35(1):12430. Available from: http://seer.ufrgs.br/index. $\mathrm{php} /$ RevistaGauchadeEnfermagem/article/ view/37032/28950

27. Xie JF, Ding SQ, Zhong ZQ, Yi QF, Zeng SN, Hu $\mathrm{JH}$. Mental health is the most important factor influencing quality of life in elderly left behind when families migrate out of rural China. Rev Latino-Am Enfermagem [online]. 2014 Mai-Jun [cited 2015 Out 01]; 22(3): 364-70. Available from: http:/ / www.ncbi. nlm.nih.gov/pmc/articles/PMC4292632/pdf/rlae22-03-0364.pdf

28. Barroso SM, Melo APS, Guimarães MDC. Depressão em comunidades quilombolas no Brasil: triagem e fatores associad. Rev Panam Salud Publica [online]. 2014 Abr [cited 2015 Out 01]; 35(4):256-63. Available from: http://www.scielosp.org/pdf/rpsp/v35n4/04. pdf

29. Carreira L, Botelho MR, Matos PCB, Torres MM, Salci MA. Prevalência de depressão em idosos institucionalizados. Rev Enferm UERJ [online]. 2011 Abr-Jun [cited 2015 Out 01]; 19:268-73. Available from: http://www.facenf.uerj.br/v19n2/v19n2a16.pdf 